The photographs serve to emphasise specific historical moments by capturing images of the social life of Chinese medicine in America and China. The notes that accompany each chapter are rich with detail for those who wish to follow-up particular aspects of this history. It is a valuable and clearly written account of a personal and professional journey into the diverse communities of practitioners of traditional Chinese medicine.

Other-Worldly illustrates the creation of many traditional Chinese medicines, in diverse geographical locations, canvassing both what they have in common and the differences that enrich them. As a text, it demonstrates the 'local creation of universality' and the contributions of both American and Chinese history and social formation to a transnational assemblage with sites in both countries.

Assunta Hunter

Centre for Health and Society,

University of Melbourne

\section{Living Memory: The Social Aesthetics of Language in a Northern Italian Town}

\section{J. R. Cavanaugh.}

Malden, MA: Wiley-Blackwell, 2009. xviii+252 pp. ISBN 978-1405168823. USD \$89.95 (Hc).

In her book, Living Memory: The Social Aesthetics of Language in a Northern Italian Town, Jillian Cavanaugh depicts present and past ideologies around an Italian dialect, Bergamasco, spoken in the northern Italian town of Bergamo. In the book's six chapters, Cavanaugh explores 'the social aesthetics of language', a perspective that takes seriously not just verbal art, but the everyday focus on the form of utterance (as in poetics) and related forms of evaluation. Artfully shifting from micro- to macro-analysis, she describes 'how this aesthetics is embedded within and informed by institutions and processes of power, such as the national government and increasing Europeanization' (p. 23). Chapter 1 introduces the city of Bergamo, her field site, along with the book's theoretical framework. In
Chapter 2, Cavanaugh turns to everyday language use, detailing multiple and interconnected varieties of Bergamasco in everyday conversations. A close consideration of these 'heteroglossic practices and language ideologies', argues Cavanaugh, 'allows for a nuanced understanding of the social aesthetics of language in Bergamo' (p. 62). In the third chapter, the author offers a more nuanced portrait of her speakers by adding a critical dimension to her analysis of the social aesthetics of language: gender. Cavanaugh argues that Bergamasco is the dialect normatively used by men, who feel comfortable using it, while women are considered less attractive when they speak it. Unlike men, women are not supposed to produce poetry or theatrical pieces in Bergamasco, and they have a very minor role in institutions created for preserving Bergamasco, such as the Ducato di Piazza Pontida. She also notes ironies that exist between the role of women as caregivers who are expected to teach standard Italian to their children, and the requirement that they abandon Bergamasco.

Cavanaugh continues her analysis of the social aesthetics of language in the fourth chapter by looking at overt forms of aesthetics, specifically poetry and theatre in Bergamasco dialect, which are also two important domains for dialect preservation and promotion. In chapter 5, Cavanaugh moves beyond discursive practices per se by considering transformations in the city of Bergamo, especially in Città Alta (upper city), a medieval part of Bergamo that has been undergoing tremendous change in recent decades. Of special interest is the fact that the city has become a museum for tourists, and in this she looks at the ideologically drawn parallel between Bergamo and Bergamasco. Chapter 6, the final chapter, shifts to an even broader perspective, examining Bergamasco and its social aesthetics within wider political contestation about the place of Italy in Europe. The author mentions the recent influence of the federalist and anti-immigrant political party Lega Nord, the 'Northern League'. She also notes the related influence of the recent waves of immigrants to Italy, which have coincided with ideological efforts to preserve the regional 
dialect of Bergamasco and reject foreigners. While the author mentions debates over foreign migrants led by the Northern League, as well as the related calls for regional preservation and federalist politics, this chapter feels somewhat disconnected from the rest of the book, because it does not clearly address changes in the social aesthetics of language under these recent conditions.

In closing, Cavanaugh's is a praiseworthy depiction of the social aesthetics of Bergamasco. The book is also an important contribution to the study and understanding of language change and the preservation of minority languages. It helps that the book is engaging and offers well-written ethnographic prose. Cavanaugh's depiction of the places where she lived and the people with whom she worked, the narratives she recounts and the abundance of richly detailed, enticing exchanges involving Bergamasco dialect, makes this book very attractive- and accessible, for both undergraduate and graduate teaching. In addition to its relevance for linguistic and cultural anthropology, and in folklore studies, this book could and should be used in Romance Language Departments as well.

Sabina Perrino

Department of Romance Languages and Literatures, Department of Anthropology, University of Michigan, Ann Arbor 